position of the groove for the meatus on the posterior face of the squamosal in many therapsids.

Such changes would bring the 'reptilian' tympanic membrane over the back of the articular. This also fits well into the scheme of regional plastic changes in the skull during the therapsid-mammal transition previously described ${ }^{6}$. It is probable that the processus lateralis of the malleus is a relic of an earlier attachment of a tympanic membrane on the articular - probably of the old reptilian tympanum at a stage when the dentalo-squamosal articulation had become the adult jaw articulation, so that the articular was relatively immobile.

The Chordafalten would then seem to be the reduced and compressed equivalent of the tissues which laterally separated the upper part of the tympanic cavity of therapsids from the recessus mandibularis. Their relations to the chorda tympani, to the malleus and goniale, to the tensor tympani and to the enlarged tympanic annulus, can readily be understood in this way (ef. Figs. 1-3). It should be noted that a compressed posterior Chordafalte would not result if a depressor mandibulæ muscle of ordinary reptilian ('sauropsid') type were present. But in the higher therapsids the 'loose' quadrate and the delicately built articular region make it clear that the jaw musculature cannot have been closely comparable with that in, for example, lizards. It seems probable that at least some of the more mammal-like reptiles had already some 'mammalian' characters in the muscles for opening the jaws. In monotremes this is done by the detrahens mandibulæ (a slip from the adductor externus group), while other mammals have developed a digastric (from the intermandibularis and interhyoideus musculature). This supports the suggestion that mammals are not monophyletic. Parallel evolution in higher therapsids is well known, and in many structures the trend is towards a mammalian pattern ; Olson ${ }^{7}$ has recently demonstrated several new and striking trends. If more than one therapsid stock gave rise to mammals, the great similarity in the tympanic membrane and related structures in all mammals suggests either a further example of very closely parallel evolution, or that, in at least some therapsids, the outer membranous wall of the recessus mandibularis had already assumed some kind of tympanic function.

The therapsid and sauropsid reptiles differ in so many ways that any advance in understanding of these problems can come only from palæontological evidence combined with a study of the anatomy (particularly developmental) of generalized mammals.

Finally, it should be noted that the accessory 'dermal' elements associated with the malleus may not be correctly homologized within the group. The ossiculum accessorium malleoli and the goniale need the most careful re-investigation, but their relations in Chrysochloris in particular support the tentative homologies previously suggested ${ }^{1}$.

Department of Geology and Mineralogy,

T. S. Westoll. University of Aberdeen. Nov. 24.

Westoll, T. S., Nature, 154, 770 (1944).

'Westoll, T. S., Proc. Roy. Soc., B, 181, 393 (1943).

${ }^{3}$ Bondy, G., Anat. Hefte, I Abt. (Arb. Anatom. Inst), 35 (Heft 106), $293(1907) ; 87$ (Heft 113), 591 (1908).

- van der Klaauw, C. J., Z. gesamte Anat., III Abt. (Ergebn. Anat. Entw.-Gesch.), 25, 565 (1924).

s van der Klaauw, C. J., Bull. Amer. Mus. Nat. Hist., 62, 1 (1931).

- Parrington, F. R., and Westoll, T. S., Phil. Trans., B, 280, 305 (1940).

z Olson, E. C., Geol. Soc. Amer., Spec. Pap., 55 (1944).

\section{New Observations on Uronema}

Uronema indicum growing as an epiphyte on aquatic plants in July at Allahabad, India, has been studied in natural as well as cultural conditions. In Nature the filaments were about $6 \mathrm{~mm}$. long, but in culture they attained a length of $4 \cdot 2 \mathrm{~cm}$. The cells showed wide variations, even in Nature. Usually they were 14-19 $\mu$ long and 6-14 $\mu$ broad and had a chloroplast occupying the whole length of the cell. In many cases the cells, $\epsilon$ specially those near the tip, were much longer $(40 \cdot 3 \mu)$ and had the chloroplast only in the middle. The size of the filament and cells and the extent of the chloroplast within the cell have been made the chief features for differentiating the various species of Uronema. The above observations show that such variations may also be due to ecological conditions.

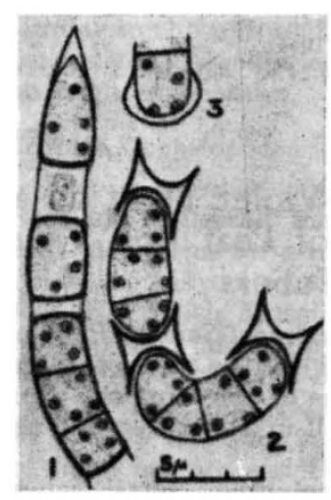

No method by which Uronema perennates has so far been reported. This species was found to perennate by means of akinetes under both natural and cultural conditions. The akinetes were formed in Nature on desiccation or on approach of winter and in culture due to overcrowding or growth in continuous strong light. The akinetes had only a slightly thick ned wall and were single or more usually composed of a row of cells (Fig. 1). When put in tap water, even after three months the cells of the akinete (from both Nature and culture) began to elongate, thereby rupturing the wall which for a time remained attached to the end as H-pieces (Fig. 2). The terminal cell gradually became acuminate and the basal cell acquired a hyaline mucous pad for attachment (Fig. 3). Further growth and cell division resulted in a long filament.

\section{Department of Botany, University, Allahabad. Sept. 10.}

\section{A. K. Mrtra.}

\section{Origin of Viruses}

IN recent times two abnormalities have arisen in the apple Lord Lambourne when this variety has been grafted on to certain other kinds : (1) where the branches and growth lack rigidity, so that the weight of even a few fruits pulls the branches almost vertically to the ground, (2) where the fruit only develops about a quarter of normal size. Thus when Lambourne has been grafted on to the variety Excelsior, Lambourne has developed non-rigid growth, and when grafted on to Redcoat Grieve it has developed the small-fruit abnormality. The same reactions have occurred in Lambourne when it has been grafted on to certain other kinds.

The behaviour of the abnormalities ${ }^{1}$ suggests they are of the nature of viruses and that they have arisen directly by grafting, that is to say, by the invasion of the cells of one variety by the proteins of another. In some cases where the abnormalities have arisen three individuals have been grafted 